\title{
IAMJ
}

INTERNATIONAL

AYURVEDIC

MEDICAL JOURNAL

ISSN: 23205091

Impact Factor: 5.344

\section{APPLICABILITY OF CHARAKA SAMHITA IN PRESENT ERA TO HAVE HEALTHY PROGENY}

\author{
Avula Srinivas \\ MD (Ayu Samhita), Associate Professor, Dept of Samhita Siddhantha \\ NK Jabshetty Ayurvedic Medical College, Gumpha, Bidar, Karnataka, India
}

Corresponding Author: srinivasonu16@gmail.com

\section{https://doi.org/10.46607/iamj10p4052020}

(Published online: July 2020)

Open Access

(C) International Ayurvedic Medical Journal, India 2020

Article Received: 01/08/2020 - Peer Reviewed: 23/08/2020 - Accepted for Publication: 24/08/2020

\section{Check for updates}

\begin{abstract}
Modern civilization has some hazards effect over humanity. Now a day's people are suffering from many diseases. Infertility is one which affects the person individually and socially. In Charaka Samhita different aspects of human such as normal Shukra, normal Aartava, importance of psychological stability, normal Khsetra (uterus) which are essential to conceive has been described. In Charaka Samhita in detail description is available about Shukra, its normal properties, defects and their management. The description about Aartava is also available regarding its normalcy, defects and management. There is also description about the genetic occurrence of diseases and majors to counteract those calamities in order to perceive a good progeny. In Charaka Samhita there is description about Garbhotpadaka Shukra other than Prakruta Shukra and Garbhotpadaka Aartava other than Aartava which flows for five days during menstruation. Here an attempt has been made to review and summarize the concept of Charaka Samhita about conception such as Shukra, Aartava their deformities, and measures to be adopted to correct them. The concepts of Charaka Samhita about genetics, transmission of genetic diseases from parents to offsprings, measures to avoid the transmission of genetic disorders such as body purification, principle of Atulya Gotra Shaarira have been discussed.
\end{abstract}

Keywords: Charakasamhita, Shukra, Aartava, Conception. 


\section{INTRODUCTION}

A human life is a combination of different emotions such as happiness, sorrow, anger, forgiveness and many more. Everyone is always thirsty for happiness. The thing which pleases to human is none other than having a good progeny. Infertility is an obstacle to have a progeny. Infertility is one which affects the person individually and socially. The modern civilization has gifted many hazards to human being as due to improper diet and daily routine people are unable to maintain health properly.

The Shukra and Aartava are the essential component for conception. ${ }^{1}$ if any impairment occurs among them individually or among both then it will lead to infertility and person will not be able to have a progeny. Fertilization of the ovum normally takes place in the ampulla of one of the fallopian tubes soon after both the sperm and the ovum enter the ampulla. ${ }^{2}$

In Charaka Samhita there is description about conception such as Shukra, Aartava their normal properties, deformities, measures to be adopted to correct them and to have a good progeny.

Aim: To understand the applicability of Charaka Samhita to have a good progeny.

\section{Objectives:}

To study the Garbhotpadaka Shukra as per Charaka Samhita

To study the Garbhotpadaka Aartava as per Charaka Samhita

Materials and Methods:

Charaka Samhita with Chakrapani commentary Modern books.

The components essential for Garbhasambhava (embryo formation)

In Charaka Samhita there is description about all the factors which required for the conception. All aspects which are essential are described such as wholesome diet, proper time for conception, Shukra, Shonita and Jeeva.

During the menstrual cycle normal Shukra, normal Streebeeja (Apradushta Yonishonita) fusion occurs in uterus then formation of embryo occurs. ${ }^{3}$ The combination of Shukra, Shonita and Jeeva occurs in Garbhashaya leads to the formation of embryo. ${ }^{4}$
Shukra, Aartava proper timing, wholesome diet are the responsible for the formation of embryo and its proper nourishment ${ }^{5}$

Shukra Dhatu: This is the important component contributing from the male in the process of conception. The deformity in this causes the male infertility. The Shukra is formed from Vayu, Agni, Bhumi, Aapa Mahabhutas and six Rasa of food. ${ }^{6}$ The normal Shukra is important in formation of embryo the importance of Shuddha Shukra has been underlined with following example. How the seed does not grow which has been infected by Kala, Ambu, Krimi, Keeta in the same manner the Shukra which has been infected does not able to form an embryo. ${ }^{7}$

Prakrutashukralaxana: In Charaka Samhita there is description about the normal Shukra, with the help of these signs we can understand the normalcy of Shukra. Apart from this the signs of Shukra which is good for conception have been described.

Snigdha, Ghana, Pischila, Madhura, Avidahi, resembelece the Sphatika are the signs of pure Shukra. ${ }^{8}$ The Shukra possessing the Bahala, Madhura, Snigdha, Avistra, Guru, Pischila, white in colour these properties are good for conception. ${ }^{9}$

Shukradushtikarana: As seed gets infected by Kala, Ambu, Krimi, Keeta likewise the Shukra Dhatu get afflicted due to following reasons. The intake of Ruksha, Tikta, Kashay, Lavan, Amla Ushan diet, no desire for women, Chinta, Shoka, Krodha, improper administration of Shastrakarma, Ksharakarma, Agnikarma, suffering from chronic diseases, Vegadhara$n a$ due to these reasons Dosha get vitiated then either individually or in combination vitiate the Shukra Dhatu. $^{10}$

Shukradoshas: The eight Shukradosha (seminal disorders) has been described in Charaka Samhita. ${ }^{11}$ Phenil, Tanu, Ruksha, Vivarna, Puti, Pischila, Anyadhatupsamsrushth, Avasadi these are the eight Doshas of Shukra. The detail description of these dosha their cause and sign symptoms has been described in Charaka Samhita. ${ }^{12}$ 
Treatment of Shukradosha: ${ }^{13}$ How the infected seeds cannot get germinated in the same way the Shukra which is having Dosha cannot produce an embryo. In Charaka Samhita different measures are being described as per Doshic involvement and in general.

Jeevaniyaghrita, Chvyanaprasha, Shilajita administration cures the seminal disorders.

As per Doshic affliction treatment has been described

Vatika: Niruhabasti Anuvasanabasti,

Pittaja: Abhayamalaki Rasayana, Amrutaaamlaki Rasayan

Kaphaja: Triphala Rasayana, Bhallataka Rasayan. Diet $:{ }^{14}$ Ghee milk, meat soup, Shaali, Yava, Godhuma, Shashtika are the wholesome diet for seminal disorders.

Prakruta Aartavalaxana (Properties of Shudha Aartava $)^{15}$ : Aartava is the important component contributing from the female in the process of conception. The deformity in this causes the female infertility. Properties of Shudha Aartava have been described in Charaka Samhita as follows. The normal menstruation occurs monthly and last for the five days. The flow is neither more nor less. The colour of the menstrual blood resembles as that of Gunjaphala (abrusprecatorius) Padma (pink colour lotus), Indragopa.

Here Chakrapani commented about the duration of Aartava kala as five days and twelve days. The differentiation about duration has been made as five days for the flow of menstrual blood. The twelve days Aartava is Garbha Ambhakatvm Aartvaa, the one which is essential for the formation of embryo. ${ }^{16}$ This duration resembles the period of ovulation.

Ovulation: Ovulation in a woman who has a normal 28 days female sexual cycle occurs 14 days after the onset of menstruation. ${ }^{17}$ Surge of LH is necessary for final follicular growth and ovulation. Without this hormone even when large quantities of FSH are available the follicle will not progress to the stage of ovulation .about two days before ovulation the rate of secretion of LH increases about 6 to 10 fold and peaking about 16 hours before ovulation. ${ }^{18}$ Preovulatory surge of LH and FSH occurs about 11.5 to 12 days after onset of monthly cycle. ${ }^{19}$
Yonivyapata: The gynaecological diseases are also one of the measure obstacles to achieve the conception. Until and unless any gynaecological disease persists the conception will not occur. In Charaka Samhita almost all the gynaecological diseases are being discussed under Yonivyapat with respect to its causes, sign symptoms and management. ${ }^{20}$

Treatment of Aartavadosha: When any gynaecological diseases occur follow the principles and management of Yonivyapat. The treatment of Aartavadosha should be follow as per the principles of Pradara, Raktapitta, Raktarsha and Raktatisara. ${ }^{21}$ Pushyanugachurna has been described in context of Pradara.

Genetic inheritance of diseases: The genetics deals with the transformation of the paternal characteristics, inheritance of diseases to offsprings. The genetic inheritance of diseases has been described in Charaka Samhita. The Beeja (Shukra and Aartava) is responsible for the genetic inheritance of diseases. The Beejavayav which is been afflicted during conception, afterwards the disease manifest in that system or organ. ${ }^{22}$

The diseases such as Premeha, ${ }^{23}$ Yonivyapat $^{24}$, Arsha ${ }^{25}$ occurs due to Beejadushti. This proves that the transformation of diseases from one generation to next is described in Charaka Samhita.

Concept of Atulya Gotra: To minimize the inheritance of diseases to next generation and to have a healthy progeny this concept has been described in Charaka Samhita. The male and female partners should not belong to same Gotra, as it is not indicated in Dharmashastra. ${ }^{26}$

Consanguineous marriages ${ }^{27}$ : When blood relatives marry each other there is an increased risk in the offspring of traits controlled by recessive genes, and those determined by polygenes. Examples are albinism, alkaptonuria, phenylketonuria and several others. An increased risk of premature death is also noted in such offspring. For instance in a certain Japanese city, a death rate of 116 per 1000 was found during the first eight years of life amongst the offspring's of first cousins, against fifty five amongst the controls, Therefore lowering of consanguineous marriages would be advantageous to the health of community. 
When we look scientifically about the principle of Atulya gotra it shows that if conception occurs between same relations the probability chance of inheritance of genetic disorder increases. This signifies the importance of Charaka Samhita to focus on the prevention of genetic diseases to get inherited from one generation to next generation.

Importance of women: The Charaka Samhita underlies the importance of women in human life in all aspects as a woman is important for affection, conception, dharma, maintenances economy of home. So, here signifies the importance of women in personal and social life. ${ }^{28}$

\section{Obstacles in conception:}

Charaka Samhita narrated all the factors which are essential to have a good progeny. Not only the presence of normal Shukra and Aartava but also other factors are also essential in formation of embryo. These all factors have been described in Charaka Samhita as obstacles in conception.

The gynaecological disorders, psychological disturbances afflicted Shukra Aartva, unwholesome food, improper conduct of life, intercourse at improper time these conditions are the obstacles in formation of embryo. $^{29}$

Vajikarana: Vajikarana is among the eight branches of Ayurveda which deals with the improvement in Shukra Dhatu. In Vajikarana concept different formulations have been described to improve quality and quantity of Shukra Dhatu such as Apatyakarishashtikadi Gutika, ${ }^{30}$ Bruhanigutika, Vajikaranaghrita, Apatyakara Ghrita. ${ }^{31}$

\section{DISCUSSION}

In Charaka Samhita the scientific description is available about conception and the components which are essential for the conception. Shukra Dhatu has been described in detail with respect to its normal characters, characters of vitiated Shukra, measures to be adopted to correct the vitiated Shukra Dhatu.

The description of Aartava is also present with normal Aartava characters, duration of menstrual flow, vitiated Aartava Laxanas and its management. Chakrapani commented about the duration of Aartava
Kala as twelve days. This Aartava is one which is essential for the formation of embryo this underlies the ovulation phenomenon also been described in Charaka Samhita. Importance of not only physical but psychological stability has been also described. Despite normal semen and ovulation couples didn't get conceived the reason about that is also described.

The genetic inheritance of diseases and measures to be adopted to counteract them has been elaborated. The probability chance of inheritance of genetic disorder increases when the conception occurs between same relations, this signifies the importance of Charaka Samhita to focus on the prevention of genetic diseases to get inherited from one generation to next generation.

This proves that the principles of Charaka Samhita are applicable in present era to have a good progeny.

\section{CONCLUSION}

From above description conclusion can be drawn as all the components which are essential for the formation of embryo have been described in Charaka Samhita. The Shukra and Aartava should be in pure form for the formation of embryo. Garbha Arambhakatvm Aartvaa has been described with duration of twelve days; this signifies that the ovulation phenomenon has been described in Charaka Samhita. The importance of psychological stability in conception has been underlined.

The principles of genetics and the law of inheritance of genetic diseases have been described in Charaka Samhita. The measures to minimize the inheritance of genetic diseases concept of Atulya Gotra have been described. Hence this is to conclude that the principles of Charaka Samhita are applicable in present era to have a good progeny.

\section{REFERENCES}

1. Acharya J. T., Charakasamhita By Agnivesha, Revised By Charaka And Dridhabala With The Ayurveddipika Commentary Of Chakrapanidatta, Chaukhambha Publications, New Delhi, Reprint 2017, P.N.308

2. Guyton And Hall, Textbook of Medical Physiology, Elsevier, New Delhi, $11^{\text {th }}$ Edition, 2007, Chapter 82 P.N.1027. 
3. Acharya J. T., Charakasamhita By Agnivesha, Revised By Charaka And Dridhabala With The Ayurveddipika Commentary Of Chakrapanidatta, Chaukhambha Publications, New Delhi, Reprint 2017, P.N.308

4. Acharya J. T., Charakasamhita By Agnivesha, Revised By Charaka And Dridhabala With The Ayurveddipika Commentary Of Chakrapanidatta, Chaukhambha Publications, New Delhi, Reprint 2017, P.N.302

5. Acharya J. T., Charakasamhita By Agnivesha, Revised By Charaka And Dridhabala With The Ayurveddipika Commentary Of Chakrapanidatta, Chaukhambha Publications, New Delhi, Reprint 2017, P.N.302

6. Acharya J. T., Charakasamhita By Agnivesha, Revised By Charaka And Dridhabala With The Ayurveddipika Commentary Of Chakrapanidatta, Chaukhambha Publications, New Delhi, Reprint 2017, P.N.302

7. Acharya J. T., Charakasamhita By Agnivesha, Revised By Charaka And Dridhabala With The Ayurveddipika Commentary Of Chakrapanidatta, Chaukhambha Publications, New Delhi, Reprint 2017, P.N.640.

8. Acharya J. T., Charakasamhita By Agnivesha, Revised By Charaka And Dridhabala With The Ayurveddipika Commentary Of Chakrapanidatta, Chaukhambha Publications, New Delhi, Reprint 2017, P.N.640.

9. Acharya J. T., Charakasamhita By Agnivesha, Revised By Charaka And Dridhabala With The Ayurveddipika Commentary Of Chakrapanidatta, Chaukhambha Publications, New Delhi, Reprint 2017, P.N.397

10. Acharya J. T., Charakasamhita By Agnivesha, Revised By Charaka And Dridhabala With The Ayurveddipika Commentary Of Chakrapanidatta, Chaukhambha Publications, New Delhi, Reprint 2017, P.N.640.

11. Acharya J. T., Charakasamhita By Agnivesha, Revised By Charaka And Dridhabala With The Ayurveddipika Commentary Of Chakrapanidatta, Chaukhambha Publications, New Delhi, Reprint 2017, P.N.109.

12. Acharya J. T., Charakasamhita By Agnivesha, Revised By Charaka And Dridhabala With The Ayurveddipika Commentary Of Chakrapanidatta, Chaukhambha Publications, New Delhi, Reprint 2017, P.N.640.

13. Acharya J. T., Charakasamhita By Agnivesha, Revised By Charaka And Dridhabala With The Ayurveddipika Commentary Of Chakrapanidatta, Chaukhambha Publications, New Delhi, Reprint 2017, P.N.640.

14. Acharya J. T., Charakasamhita By Agnivesha, Revised By Charaka And Dridhabala With The Ayurveddipika Commentary Of Chakrapanidatta, Chaukhambha Publications, New Delhi, Reprint 2017, P.N.641.
15. Acharya J. T., Charakasamhita By Agnivesha, Revised By Charaka And Dridhabala With The Ayurveddipika Commentary Of Chakrapanidatta, Chaukhambha Publications, New Delhi, Reprint 2017, P.N.643.

16. Acharya J. T., Charakasamhita By Agnivesha, Revised By Charaka And Dridhabala With The Ayurveddipika Commentary Of Chakrapanidatta, Chaukhambha Publications, New Delhi, Reprint 2017, P.N.643.

17. Guyton And Hall, Textbook Of Medical Physiology, Elsevier, New Delhi, 11 ${ }^{\text {th }}$ Edition, 2007, Chapter 81 P.N. 1014

18. Guyton And Hall, Textbook Of Medical Physiology, Elsevier, New Delhi, 11 ${ }^{\text {th }}$ Edition, 2007, Chapter 81 P.N. 1014

19. Guyton And Hall, Textbook Of Medical Physiology, Elsevier, New Delhi, 11 ${ }^{\text {th }}$ Edition, 2007, Chapter 81 P.N. 1021.

20. Acharya J. T., Charakasamhita By Agnivesha, Revised By Charaka And Dridhabala With The Ayurveddipika Commentary Of Chakrapanidatta, Chaukhambha Publications, New Delhi, Reprint 2017, P.N.634-640.

21. Acharya J. T., Charakasamhita By Agnivesha, Revised By Charaka And Dridhabala With The Ayurveddipika Commentary Of Chakrapanidatta, Chaukhambha Publications, New Delhi, Reprint 2017, P.N.643.

22. Acharya J. T., Charakasamhita By Agnivesha, Revised By Charaka And Dridhabala With The Ayurveddipika Commentary Of Chakrapanidatta, Chaukhambha Publications, New Delhi, Reprint 2017, P.N 321,322

23. Acharya J. T., Charakasamhita By Agnivesha, Revised By Charaka And Dridhabala With The Ayurveddipika Commentary Of Chakrapanidatta, Chaukhambha Publications, New Delhi, Reprint 2017, P.N 449

24. Acharya J. T., Charakasamhita By Agnivesha, Revised By Charaka And Dridhabala With The Ayurveddipika Commentary Of Chakrapanidatta, Chaukhambha Publications, New Delhi, Reprint 2017, P.N 634,635

25. Acharya J. T., Charakasamhita By Agnivesha, Revised By Charaka And Dridhabala With The Ayurveddipika Commentary Of Chakrapanidatta, Chaukhambha Publications, New Delhi, Reprint 2017, P.N 501.

26. Acharya J. T., Charakasamhita By Agnivesha, Revised By Charaka And Dridhabala With The Ayurveddipika Commentary Of Chakrapanidatta, Chaukhambha Publications, New Delhi, Reprint 2017, P.N.302

27. K. Park, Parks Textbook of Preventive And Social Medicine, M/S Banarsidasbhanot Publishers, Jabalpur, $18^{\text {th }}$ Edition 2005, Chapter 16, P.N.629. 
28. Acharya J. T., Charakasamhita By Agnivesha, Revised By Charaka And Dridhabala With The Ayurveddipika Commentary Of Chakrapanidatta, Chaukhambha Publications, New Delhi, Reprint 2017, P.N.690.

29. Acharya J. T., Charakasamhita By Agnivesha, Revised By Charaka And Dridhabala With The Ayurveddipika Commentary Of Chakrapanidatta, Chaukhambha Publications, New Delhi, Reprint 2017, P.N.302.

30. Acharya J. T., Charakasamhita By Agnivesha, Revised By Charaka And Dridhabala With The Ayurveddipika Commentary Of Chakrapanidatta, Chaukhambha Publications, New Delhi, Reprint 2017, P.N.392-393.

31. Acharya J. T., Charakasamhita By Agnivesha, Revised By Charaka And Dridhabala With The Ayurveddipika Commentary Of Chakrapanidatta, Chaukhambha Publications, New Delhi, Reprint 2017, P.N.391.

\section{Source of Support: Nil}

\section{Conflict of Interest: None Declared}

How to cite this URL: Avula Srinivas: Applicability Of Charaka Samhita In Present Era To Have Healthy Progeny. International Ayurvedic Medical Journal \{online\} 2020 \{cited July, 2020\} Available from: http://www.iamj.in/posts/images/upload/2427_2432.pdf 